\title{
Security and Defense Policy in the New European \\ Constitution: A Critical Assessment
}

\author{
Tuomas Forsberg *
}

\section{Introduction}

Is the European Union ever going to be a credible actor in international politics? In the aftermath of the war on Iraq, many analysts tend to answer in the negative. But those who are more optimistic about the process of European integration may point to the new EU treaty that is also known as the "European Constitution" as a positive achievement. ${ }^{1}$ Besides trying to settle the institutional questions of the enlarged Union for a longer period of time, it represents an attempt to transform and strengthen the Union as an international actor.

The EU's new Constitutional Treaty is historic not only because of its ambitions to serve as a bedrock for the future enlarged Union but also because of its method of preparation. It was drafted in 2002-3 by the European Convention, in which both European institutions as well as national governments and parliaments were represented. The convention submitted a draft that was finalized as usual by the Intergovernmental Conference (IGC) of the member states. ${ }^{2}$ The conclusion of the treaty was once imperiled, in December 2003, due to questions mainly related to voting power issues, but it was finally accepted at the European Council meeting in June 2004 by the heads of the twenty-five member states. The treaty needs to be first signed and then ratified before entering into force, which in many EU countries requires a positive vote in a referendum.

Regardless of the difficulties the treaty may be facing in the ratification process, it is imperative to analyze its implications for European policy-making. My focus in this essay will be on the foreign and security policy aspects of the constitution. I will argue that the treaty is a step forward, but not as large a step as it could be, since intergovernmentalism and unanimity tend to prevail in foreign and security policy. As a result of political compromises, it also includes a number of contradictions and obscure elements that will not work to its long-term benefit. I will first deal with both the consensual parts of the treaty, such as the solidarity clause and the foreign minister, and pay then special attention to more contested parts of the treaty, namely those of the Euro-

\footnotetext{
* Dr. Forsberg is a professor in the Department of Political Science at the University of Helsinki.

1 "Provisional Consolidated Version of the Draft Treaty Establishing a Constitution for Europe," CIG 86/04, Conference of the Representatives of the Governments of the Member States, Brussels, 25 June 2004, available at: http://ue.eu.int/ueDocs/cms_Data/docs/ pressdata/en/misc/81243.pdf; and "Draft Treaty Establishing a Constitution for Europe," CONV 850/03, The European Convention, the Secretariat. Brussels, 18 July 2003, available at: http://european-convention.eu.int/docs/Treaty/cv00850.en03.pdf.

2 Peter Norman, The Accidental Constitution (Brussels: EuroComments, 2004).
} 
pean Council President, the collective defense clause (closer cooperation), and the capability core (structured cooperation). I will, however, begin by explaining the principles of assessment, because in most analyses of the convention draft they have not been made explicit. These analyses will, however, serve as important reference points for my own evaluation. ${ }^{3}$

\section{Criteria for Assessment}

How should we assess the new constitutional treaty? There are many ways to approach the issue, but I propose here three important criteria: clarity, effectiveness, and democracy and transparency. I will also reject one factor that often plays an important rolenamely, political feasibility.

Many of us remember Napoleon's famous dictum that "a good constitution must be short and obscure." If Napoleon were to assess the new European constitution, he would probably note that it fulfills only the second requirement. Indeed, most of the present criticism of the constitution tends to characterize it as both too long and too obscure. Indeed, since the stated aim of the drafters was to condense and clarify the current treaty texts, concision and clarity must be one basis of assessing the success of the convention proposal for the European Constitution. These criteria do not include only that the individual articles be understandable, but also that the treaty and its parts form a coherent whole.

Yet the real goals of the constitution were much more ambitious than making mere technical improvements to the old treaties. The aim was to advance European unity and common interests. In this regard, the drafters had to confront yet another dictum that is attributed to Napoleon's contemporary, the counter-enlightenment philosopher Joseph de Maistre; in his opinion, "a constitution that is made for all nations is made for none." Nevertheless, since the European constitution is intended for all European na-

3 These include: Steven Everts and Daniel Keohane, "The European Convention and EU Foreign Policy: Learning from Failure," Survival 45:3 (2003): 167-86; Stefan Griller, "External Relations," in Ten Reflections on the Constitutional Treaty for Europe, ed. Bruno de Witte (Florence: The European University Institute, 2003), 133-58; Lisbet Zilmer-Johns, "The Convention, the IGC and the Great Powers. The ESDP and the New Security Threats," in The Politics of European Security, ed. Jess Pilegaard (Copenhagen: Danish Institute of International Affairs, 2004), 55-82; Wolfgang Wessels, "Eine institutionelle Architektur für eine globale (Zivil-)Macht? Die Artikel zur Gemeinsamen Außen- und Sicherheitspolitik des Vertrags über eine Verfassung für Europa," Beitrag für die Zeitschrift ZSE, Cologne (July 2003); Nadia Klein and Wolfgang Wessels, "Eine Stimme, zwei Hüte - viele Pionere? Die Gemeinsame Außen- und Sicherheitspolitik nach dem EU-Konvent," WeltTrends 42 (Spring 2004): 11-26; Claus Giering, ed., Der EU Reformkonvent - Analyse und Dokumentation (Gütersloh/Munich: Bertelsmann-Stiftung/Center for Applied Policy Studies, 2003); Simon Duke, "The Convention, the Draft Constitution and External Relations: Effects and Implications for the EU and its International Role," Working Paper no. 2003/W/2 (Maastricht: European Institute of Public Administration, 2003). 
tions - and, indeed, for the European people - another criterion for assessment must be the extent to which the constitution fosters the European cause, however it is defined.

The immediate problem with this almost self-evident point of departure for any impartial analysis of the constitution is that the concepts of "common values" or "fundamental interests" (Art. III-188) are utterly contested and open-ended. For example, some argue that "flexibility" is good for Europe, while others believe that "coherence" should be the primary goal. Because I do not claim that I- or any other independent analyst - would know exactly how to define these concepts, it is important to justify why certain proposals could be seen as better for "Europe" than others on a case-bycase basis. It is, of course, impossible to convince Euro-skeptic non-believers (at least within the limits of this paper) that any policies should be decided on a European rather than on the national (or, for that matter, global) level. As Andrew Moravcik has aptly pointed out, most scholars, commentators, and practitioners of EU politics tend to reflexively favor deeper European integration, often with little regard to whether it has a strong practical justification in any specific case. ${ }^{4}$ Therefore the preference for European integration has to be taken as a presumption rather than an argument of this analysis, although I will try to make some arguments as to why the European Union should be stronger and more effective.

Along with clarity and the European interest, there is a third criterion that is closely linked to these but must be mentioned separately: democratic accountability and transparency. This is also a very contested issue, inasmuch as it is unclear whether European executives should be accountable to the European parliament or, via the governments of the member states, to national parliaments. The jury sitting in judgment on this question of "democratic deficit" is still out, but it seems that we need some sort of combination of these two principles. ${ }^{5}$ The convention draft itself referred to Thucydides' definition of democracy to mean that the "power is in the hands of the greatest numbers." Moreover, to increase democratic control, the constitution should promote openness in decision-making, although the extent that can be adopted in security affairs is debatable.

Before moving into analysis, a fourth criterion for assessment must be mentionednamely, how realistic the proposals or counter-proposals are. Arguments that belong to this category can refer to the need to "preserve the institutional balance" (without further justification of why the balance is worth preserving), and may feature warnings about opening a "Pandora's box" if changes to the proposal are suggested. Such rhetoric can, of course, be used as a conservative pretext to dismiss any reforms. Moreover,

4 Andrew Moravcik, "The Myth of a European 'Leadership Crisis,"” Challenge Europe 11 (26 March 2003); available at: http://www.theepc.net.

5 Paul Magnette, Christian Lequesne, Nicolas Jabko, and Olivier Costa, "Conclusion: Diffuse Democracy in the European Union: The Pathologies of Delegation," Journal of European Public Policy 10:5 (October 2003): 834-40; Laurent Pech, "The Solution to the 'Democratic Deficit.' A New Type of Governance for the European Union," Journal of European Integration 25:2 (June 2003): 131-50; and Yves Mény, "De la Democratie en Europe: Old Concepts and New Challenges," Journal of Common Market Studies 4:1 (March 2003): 1-13. 
as often happens, a political compromise can be worse than any of the contending alternatives.

It is clear that a constitution is always a political compromise, and that ideal solutions are not always possible to achieve for political reasons, but political analysts should leave the work of negotiating conflicting interests to the politicians in the first place. The fact that something is accepted does not make it necessarily good, and vice versa. Although we need some reality-checks in our thinking, proposals that have once been labeled as utopian dreams have from time to time come true, and we should not conflate substantial arguments with political power relations. In the good Habermasian spirit, all that should count in an "ideal speech-situation" are good arguments - and this was the background ideology that underpinned the convention as a preparatory mechanism for the treaty. ${ }^{6}$

\section{Foreign Minister, Armaments Agency, Petersberg Tasks, and Solidarity Clause}

The convention proposed several changes in the area of foreign and security policy, namely to the Common Foreign and Security Policy (CFSP) and European Security and Defense Policy (ESDP). Most of the proposals were accepted without much heated discussion by the governments of the member states. Neither did they evoke much critical attention from the community of Euro-observers and CFSP analysts. These conventional proposals include the redefinition of the military tasks that the EU can perform; the establishment of an armaments agency, a European diplomatic service, and the post of a European Foreign Minister; as well as the inclusion of a "solidarity clause" to the EU treaty.

The establishment of the post of a Union Minister for Foreign Affairs (Art. I-27) is perhaps the most important of the less controversial proposals of the draft. The minister will be responsible for conducting the Union's foreign policy both in his or her capacity of a commissioner and as chairman of the Foreign Affairs Council. He or she will have the right to make proposals in the field of common foreign and security policy, and will be responsible for overseeing its implementation.

Not only all member states (with the partial exception of Sweden) and almost all convention members, but also a clear majority of EU citizens - according to opinion polls — supported the idea of establishing the office of EU Foreign Minister. ${ }^{7}$ The wide approval for this proposal already indicates that the new EU treaty will be a significant step forward in developing the EU's standing as an international actor. For, not so many years ago, the idea of merging the two jobs of the commissioner of external affairs and the high representative of the CFSP through double-hatting was objected to

Jürgen Habermas, The Theory of Communicative Action (Boston: Beacon Press 1986).

7 See Bruno Scholl, "Wie tragfähig ist die neue institutionelle Architektur der EU? Der Verfassungsentwurf des Konvents im Spiegel nationalstaatlicher Präferenzen,” Integration 26:3 (2003): 204-17. 
simply because it seemed to contradict the pillar structure of the Union. ${ }^{8}$ During the past three years or so, however, it has become part of the received wisdom that having two separate persons working in the field of external relations was dysfunctional, and that a detrimental institutional clash was avoided only through the flexibility and personal skills of the occupants of these posts. Moreover, since the high representative of the CFSP did not have access to the economic resources of the Union, he lacked important means to back up his policy initiatives in the international arena.

Yet squaring the circle is never easy. New tensions may emerge between the president of the Commission and the foreign minister and, as we will discuss later, between the new European Council president and the foreign minister. Many are worried that the collegial nature of the commission cannot be preserved if one of the commissioners has conflicting loyalties. Nadia Klein and Wolfgang Wessels, for example, warn that the "spagat" between the two hats contains the risk that the foreign minister will fall through the cracks. ${ }^{9}$ Moreover, the new Foreign Minister will be a very busy individual, as he or she will be vice-president of the commission, will have a number of administrative duties on the council side, and will also have a very demanding travel schedule due to the need to represent the EU externally. It is unlikely that one single person can do all this effectively. Most likely, this will lead to a situation where the minister has several deputies, which again creates coordination problems and credibility gaps.

The establishment of a European External Action service, which was a late addendum to the convention draft, naturally flows from the creation of the post of foreign minister. The idea is to combine the staff resources of the council secretariat and the commission with seconded national personnel. This is also a relatively uncontroversial proposal as such, but the problems lie more in its execution. It is unclear how the diplomatic service relates to the staff that remains outside of the service but works in the area of external relations. As Simon Duke points out, there are many questions related to the creation of the EU diplomatic service that were "addressed only the most perfunctory manner in the draft Constitution." ${ }^{, 10}$ In general, there is a fear that the creation of a separate external action service will mean a de facto loss of commission influence in the area of external relations.

The establishment of an armament agency (European Armaments, Research and Military Capabilities Agency, Articles I-40(3) and III-212) was also a relatively widely accepted proposal in the constitution draft. It had been a topic of discussion for many years before the convention. ${ }^{11}$ According to the constitution, the agency has the task of identifying military capability objectives and promoting harmonization in procurement

8 The fusion was proposed for example by Gilles Andréani, Christoph Bertram, and Charles Grant, Europe's Military Revolution (London: Centre for European Reform, 2001).

9 Klein and Wessels, "Eine Stimme, zwei Hüte - viele Pionere?" 17.

10 Duke, "The Convention, The Draft Constitution and External Relation," 32.

11 See, for example, Keith Hayward, "Towards a European Weapons Procurement Process," Chaillot Paper no. 27 (Paris: Western European Union Institute for Security Studies, 1997). 
policies. The benefits of such an agency are self-evident, as it would make military expenditure more cost-effective, but the agency has limited political power and lacks the means of implementing its policy recommendations. Nor does the agency necessarily replace the existing broader and narrower forms of cooperation (like OCCAR, LoI and WEAG).

The convention also suggested (Art. III-210) that the EU extend the scope of its military-related tasks to include such tasks as disarmament, military advice, conflict prevention, and post-conflict stabilization, along with humanitarian and rescue operations, peace-keeping, and crisis management that may include the use of combat forces. This updating of the so-called Petersberg Tasks, which stem from the 1992 WEU ministerial meeting formulation and were incorporated into the EU competence list at the Amsterdam conference, was also easily accepted by the convention representatives. It merely brings the treaty into line with present reality, and it does not include the contested issues of collective defense or pre-emptive intervention. The redefinition clarifies the task list, but it hardly adds any elements that the old definition of scope had contradicted, since there was no real consensus about what the Petersberg Tasks - in particular in the more demanding "crisis management" end-really included. According to many, they could well include operations such as Allied Force; in other words, NATO's military intervention in the Kosovo crisis.

Indeed, because the idea of mutual security guarantees within the EU treaty remained controversial, as will be discussed in more detail later, the convention proposed a "solidarity clause" (Art. I-42 and III-231), according to which "the Union and its Member States shall act jointly in a spirit of solidarity, if a Member State is the victim of terrorist attack or natural or man-made disaster." The promised solidarity would entail that the Union and its member states could mobilize military instruments to assist a member state in the event of a terrorist attack.

The solidarity clause corresponds to the reality of the post-9/11 security environment. It would be very strange if the Union stood by and the member states did not help each other when one or more members were faced with terrorist threats or suffering from a serious natural or man-made disaster. Indeed, the problems that the solidarity clause raised had more to do with difficulties in defining a terrorist threat and its relation to mutual defense commitments. As terrorism is the main threat that the Union faces today, according to the EU Security Concept, the Solidarity Clause is virtually a common defense clause. ${ }^{12}$ Moreover, the well-known difficulty in defining terrorism means that any country that feels threatened - whether by a terrorist group or notcould try to define that threat as a form of terrorism. The convention working group on defense, led by Michel Barnier, had suggested that the solidarity clause would only apply to threats from non-state entities, but this restriction did not appear in the con-

12 Javier Solana, "A Secure Europe in a Better World. The European Security Strategy," Brussels, 12 December 2003; available at http://ue.eu.int/ueDocs/cms_Data/docs/pressdata/en/ reports/78367.pdf. 
vention draft of the constitution. ${ }^{13}$ During the intergovernmental conference, it was proposed that the solidarity clause would not exceed the redefined Petersberg Tasks, and it was added that decisions should be based on unanimity: this may have clarified the contradiction with the defense clause in theory, but not in practice.

\section{The European Council President}

One of the most controversial proposals in the convention draft for a European constitution was the idea of a European Council president (Art. I-21). The president, who is elected for a term of two-and-a-half years, would replace the six-month council presidency that currently rotates between the member states. The new president would have both internal and external capacity. On the one hand, the new European Council president would assume administrative functions in preparing for European Council meetings and facilitating consensus; on the other hand, he or she would represent the Union in its external relations. As Everts and Keohane suggest, he or she could, "for example, visit President Bush to discuss major international issues." 14

The weakness of the rotating council presidency has become plain, in particular in the Union's foreign policy. The problem is partly the rotation in itself, which creates discontinuity, and partly the fact that smaller member states are not regarded as credible foreign policy representatives of the Union by third parties. It is feared that both problems will be aggravated by the enlargement of the Union.

A few examples may be needed to demonstrate the existing problems. When the Union negotiated with Turkey over guaranteed access to use NATO's resources in the autumn of 2000, Ankara dismissed the country which then held the presidency (Belgium), and wanted to deal with the United Kingdom. When Moscow disagreed with steps taken by the presidency of Denmark in autumn 2002, it simply waited for countries that would be more favorable in its eyes - in this case, Greece, followed by Italy - to take the presidency before acting. The rotation also creates inconsistency and impulsiveness in the Union's external relations. Every presidency wants to achieve something in the field of foreign policy, but the short duration of the office does not allow for the systematic development of foreign policy agendas.

Of course, the rotational presidency system also has its merits, in particular familiarizing new member states with the working of the Union. In addition, the problem of the credibility of small member states could have been improved if their presidencies had been consistently supported by the other member states. The problem of inconsistency could have been mitigated through greater reliance on European institutions in preparing foreign policy agendas, as the small countries often had to do because of their lack of resources and experience in many specific issue-areas of union policies.

The main problem with the new European Council president, however, is the office's relationship and division of labor with the new Foreign Minister. As the func-

13 "Final Report of Working Group VIII - Defense," The European Convention, the Secretariat, CONV 461/02. Brussels, 16 December 2002.

14 Everts and Keohane, "The European Convention and EU Foreign Policy." 
tions of the European Council president do not remain simply ceremonial, it is almost unavoidable that he or she will compete with the foreign minister. Once the structural tension between the commissioner for external relations and the high representative for CFSP has been removed, why should one create a new potential institutional friction between the foreign minister and the European Council president? The constitution does not solve the division of labor in a satisfactory way: it says that the European Council president should act "without prejudice" to the responsibilities of the foreign minister, a clumsy expression that is always used to hide an apparent contradiction.

Moreover, the idea that the president could represent the Union in negotiations with the U.S. president is far-fetched, and is in need of more sober reevaluation. If the major powers in the Union are willing to control key areas in foreign policy decision-making, as they have so far, the role of the president will remain limited; indeed, he or she has no credible position to negotiate with the president of the United States. If the leaders of the major European powers are willing to delegate power, they are more likely to give it to the European foreign minister, who is subordinate to them. The European Council president seems to fall between the chairs.

The argument that one simply has to accept the new European Council president as a counterweight to the enhanced status of the Commission president if he or she is going to be elected by the European Parliament is not sufficient justification for the post. The foreign minister, along with groups of small and large countries forming a shared presidency for a longer period of time that will be established in other issue areas, could do the job of the Council president. ${ }^{15}$

\section{Enhanced Cooperation}

Another issue that was the subject of heated debate during the convention concerns enhanced cooperation in the field of security and defense. The convention draft of the European constitution introduced two separate forms of enhanced cooperation, namely "closer cooperation" and "structured cooperation"-the former expression later removed, and the latter changed by the IGC into "permanent structural cooperation." This is very confusing, but if a straightforward translation is allowed here, "closer cooperation" means mutual security guarantees, whereas "permanent structured cooperation" means a capability core of the Union.

The issues at stake with regard to core groups in security and defense were not new. The idea of enhanced cooperation established by a core group in security and defense has been discussed ever since the Maastricht Treaty. ${ }^{16}$ In the negotiations leading to the Nice Treaty, the idea of enhanced cooperation in defense issues was again rejected.

15 Christopher Hill, "CFSP: Conventions, Constitutions and Consequentiality," International Spectator 32:4 (2002): 75-89.

16 See Alexander Stubb, Negotiating Flexibility in the European Union (Basingstoke: Palgrave, 2002); and Thomas Jaeger, "Enhanced Cooperation in the Treaty of Nice and Flexibility in the Common Foreign and Security Policy," European Foreign Affairs Review 7:3 (2002): 297-316. 
What really pushed this old idea forward during the convention preparation was the forthcoming enlargement: it was feared that decision-making in foreign and security policy would become too complicated, as it is based on unanimity. A policy based on the lowest common denominator able to be agreed upon by twenty-five or more countries would stagnate Europe.

Yet it seemed that these fears were somewhat contradictory. Some member states were worried that the foreign policy influence of the new members could lead the Union in the "wrong direction"- that is, it would become less autonomous and more dependent of the United States. The larger countries in particular were afraid that small member states would have too much say. Writing as an independent scholar but reflecting such views, Julian Lindley-French, for example, argued that, "the strategic political correctness over the sensibilities of the smaller powers which has been instrumental in blocking the development of the CFSP/ESDP must be ended with an assertion by the great powers of strategic reality." In a report on "European Defence Strategy," he argued together with Franco Algieri that "military operational leadership must ... be exercised by a 'trirectoire' made up of Britain, France and Germany.","

There are in fact various practical examples of core group initiatives in the field of security and defense. Most famously, at the same time when the convention was meant to be developing ideas of enhanced cooperation, the so-called "gang of four"-France, Germany, Belgium, and Luxembourg - held a meeting in April 2003 which produced several initiatives for further military integration. These included a common military headquarters to be located in Tervuren, near Brussels. ${ }^{18}$ The meeting was criticized both because of its timing, which aggravated the split caused by the war on Iraq, and because of the adoption of initiatives that were seen as undermining NATO.

Another example of small group cooperation is the ad hoc meetings of the largest member states of the Union. During the Afghanistan operation in November 2001, the British Prime Minister Tony Blair hosted a dinner meeting in London to which only the German, French, Spanish, Italian, Dutch, and Belgian prime ministers were invited, along with the high representative of the CFSP, Javier Solana. Similarly, Schröder, Chirac, and Blair - the prime ministers of the three largest EU states - met in Berlin in September 2003 and again in February 2004 to try to forge a common approach to

17 Julian Lindley-French, "In the Shade of Locarno. Why European Defence is Failing," International Affairs 78:4 (2002): 789-811; and Julian Lindley French and Franco Algieri, "A European Defence Strategy," A Report by the Venusberg Group (Gütersloh: Bertelsmann Foundation, 2004). Such a proposal was also made by Andreani, Bertram, and Grant, in Europe's Military Revolution, and by Stephan Keukeleire, in "The Case for a 'Directorate' in the CESDP," in On Cores and Coalitions in the European Union, ed. Alfred Pijpers (The Hague: Clingendael Institute, 2000), 35-62. It has found support, for example, from the former Dutch commissioner Hans van den Broek and Ambassador Peter van Walsum; see Peter van Ham and Alfred Pijpers, "Laat Grote Drie Europa leiden," NRC Handelsblad (23 April 2003).

18 "EU Military Summit: The Seven Point Agreement," The Guardian (29 April 2003). 
post-war Iraq. All of these meetings were criticized by many of the not-invited member states, both big and small.

During the final negotiations, the article regarding "closer cooperation" (Art. III214) was removed by the IGC, but the remaining article (Art. I-40(7)) still creates a loose collective defense system within the Union. It states, "If a Member State is the victim of armed aggression on its territory, the other Member States shall have towards it an obligation of aid and assistance by all the means in their power." It is unclear what these defense guarantees would imply in practice, or whether this form of cooperation would primarily be a symbolic declaration of a willingness to take such commitments. At the insistence of the U.K., the Italians included a clarification during the IGC that "commitments and cooperation in this area shall be consistent with commitments under NATO" that will remain the foundation of the collective defense of its members. Still, this "core group" of collective defense was meant to be open to all member states, including those who were not members of NATO. The convention proposed that member states could join it at a later stage if they so wished simply by subscribing to the declaration. The IGC ended up accepting the interpretation that the article applies to all states, without exception.

The proposal concerning security guarantees, or "closer cooperation," at first seemed to be redundant. On the one hand, NATO stands alone as the primary organization that can provide credible security guarantees, while on the other hand the solidarity clause covers the threats that the Union is most likely to face in the near future, namely terrorist attacks. Indeed, the importance of the mutual security guarantees - if they do not imply the integration and harmonization of defense structures - is largely symbolic. And these commitments should already be more than symbolic. Even without such a clause, it is difficult to see how closely integrated member states, many of which share a common currency, could refrain from helping each other militarily if one of them were attacked. If they refused to help other member states in the name of their national interests in such an event, it is unlikely that they would have acted otherwise simply because of a written declaration.

The convention's proposal of "closer cooperation" did not evoke much attention at the early stages of deliberations, because it was regarded as optional. When the article was seen as applying to all member states, it became an issue in the post-neutral member states Austria, Finland, Ireland, and Sweden. They had believed the U.K. would block any mutual defense clause, but once the U.K. was satisfied with the change of formulation that reminded members of the prior role of NATO, the four countries woke up just before the December 2003 summit to realize that the security guarantees would be inconsistent with their national security policies - they could no longer call themselves "militarily non-aligned states." Instead, the four post-neutral states, following the lead of Finland, proposed a watered-down version of the clause: "if a Member State is victim of armed aggression, it may request the other Member States give it aid and assistance by all the means in their power, military or other in accordance with Article 51 of the UN Charter." In other words, a member state would have the right to ask for assistance, but none of them would have the obligation to give it. This formula- 
tion was clearly unacceptable from the point of view of Italy, but it was ready to offer a compromise that satisfied the "militarily non-aligned" states. Finally, the article was supplemented by an obscure statement, that "this shall not prejudice the specific character of the security and defense policy of certain member-states." 19

In contrast to this "closer cooperation" on collective defense, "permanent structured cooperation" (Art. I-40(6), Art. III-213) was not regarded as being necessarily open to all member-states. The convention proposal stipulated that structured cooperation would be established by countries that "fulfill high military capability criteria and wish to enter into more binding commitments, and in this matter with a view to the most demanding tasks." A country that would like to join this core group at the later stage could only do so if the member states taking part in structured cooperation accepted it by a qualified majority.

Although the convention proposal did not spell it out, some member states and observers feared that structured cooperation could in effect mean a directoire, or what also has emerged as a term to describe it in the unofficial language, a "European Security Council," a "triumvirate," or a "trirectoire." The treaty drafted by the convention stated that, when this core group makes decisions in the name of the Council (which they could do "in matters covered by such cooperation"), other member states could not participate in the discussions. The major concern was that this cooperation would be a closed club, although German Foreign Minister Fischer, along with his French and Belgian colleagues Villepin and Michel, had explained that "a European Security and Defense Union," which is their term for structured cooperation, should be open to all member states. ${ }^{20}$

Indeed, the article dealing with structured cooperation was seen as very unclear at best, and as the seed of a revolution within the mechanisms of security and defense policy decision-making at worst, one that was camouflaged by the article's obscure language, including the very term "structured cooperation." The opacity of the article stemmed from the lack of any protocol that would define the criteria for military capability, as well as from the total ambiguity of what really were "the matters covered by such cooperation" It did not mean specific tasks, since another article (Art. III-211) stipulated that "the Council may entrust the implementation of a task to a group of Member States which are willing and have the necessary capability for such a task."

The IGC clarified the idea of "structured cooperation" during the Italian presidency. The Protocol on Permanent Structural Cooperation now states explicitly that it is open to any member state who wants to proceed more intensively to develop its defense capabilities, contribute to multinational forces, and participate in European equipment programs. Concretely, by 2007 the member states should supply, either at

19 "Addendum to the Presidency Note," Conference of the Representatives of the Governments of the Member States, CIG 60/03 ADD 1, Brussels, 9 December 2003.

20 Mr. Villepin, Mr. Fischer and Mr. Michel, "Proposition d'amendement a l'Article 30, partie I," available at: http://european-convention.eu.int/docs/treaty/pdf/30/30de $\% 20$ Villepin FischerMichel.pdf. 
the national level or as a part of a multinational force package, targeted combat units with transport and logistics elements. In other words, the "high military capability criteria" and "binding commitments" were rendered such that clearly most (if not all) member states could qualify if they so wished - and, in fact, most of them do not want to remain aloof from such cooperation.

The idea of a core group of the most powerful member states was too sensitive to be included in the treaty, but it did not disappear as a theme for analysts and others to wrestle with. Klein and Wessels wonder whether the present regulations provide enough incentives for those members who are both willing and able to go forward. ${ }^{21}$ But one could also ask whether there are any incentives for the smaller member states to accept a formal leadership group within the Union. Although the largest member states may need to forge common positions among themselves, there is no need to institutionalize such a form of enhanced cooperation as a part of the treaty. Enhanced cooperation should be driven by substantive ideas, and not by a vision of a predetermined group. As "the quad" within NATO, so should the "big three" in the EU coordinate their policies in order to provide leadership and facilitate decision-making. Yet this coordination should remain informal; the decisions would not become EU decisions unless they were accepted by the European institutions.

Apart from the delicate question of who would belong to the group or not, there is little that can be gained by institutionalizing a directoire, and much to be lost. ${ }^{22}$ The problems of EU foreign and security policy do not stem from the resistance and unilateralism of smaller member states, but rather from the fact that the big three have not been able to agree on a common position. In the United Nations, for example, two countries that most frequently vote against the majority of the EU states are France and the United Kingdom. ${ }^{23}$ Informal forms of leadership groups are more flexible compared to institutionalized decision-making bodies. They can easily include other members, depending on the context and the issues in question. The justification that an institutionalized directoire would create more pressure to provide leadership for the Union begs for evidence. By contrast, a directoire could rather lead to centrifugal tendencies, and might force smaller member states to look for alternative channels of influence. Moreover, a small directoire in charge of decision-making within the Union would make a mockery of attempts to strengthen multilateral approaches at the global level. Indeed, the idea that more power should be given to those countries that are powerful, simply because they have power, is tautological.

There are good arguments for enhanced cooperation in defense. It is true that major progress in European integration has often resulted from core group initiatives, and the

21 Klein and Wessels, "Eine Stimme, zwei Hüte - viele Pionere?” 19.

22 Andreani, Bertram, and Grant argue that "France, Britain and Germany represent a natural leadership group," because "they represent a broad coalition of interests within the EU." Europe's Military Revolution, 85.

23 Paul Luif, "EU cohesion in the UN General Assembly," Occasional Paper no. 49 (Paris: European Union Institute for Security Studies, 2003). 
need for further cooperation in the field of security and defense cannot be denied. However, the cooperation could follow the general provisions that guide enhanced cooperation (Art. I-43, Art. III-322 - 329). ${ }^{24}$ According to those principles, the objectives and the criteria that countries are required to fulfill should be accepted commonly. Indeed, the idea of creating convergence criteria to foster European defense policy is not necessarily a bad idea. ${ }^{25}$ The constitution does not create any radical criteria for "structured cooperation," but it is now more explicit about what this means than was the convention draft.

\section{Missing Parts: Majority Decision-Making and Transparency}

Seen from the perspective of the assessment criteria laid out earlier in this article, the European Constitution suffers from two major shortcomings. First, the new EU treaty still maintains the requirement for unanimity in decision-making in the foreign and security policy arena. ${ }^{26}$ The requirement of unanimity has been one of the well-known British "red lines" regarding the treaty. There are, however, two small exceptions to the rule. First, through the initiative of the Italian presidency, the treaty makes it possible to use qualified majority voting in the Council when the European Foreign Minister makes a proposal, although the convention required unanimity also in those cases. The change will not be dramatic, because the foreign minister will still be acting under the mandate of the Council in any case. The treaty also mentions the option that the European Council can decide by unanimity that in selected issues not predefined in the treaty, the Council can adopt decisions by majority vote. Because of the previous requirement of unanimity, and the possibility that national parliaments could object to the use of this so-called passerelle clause, it is not likely to change the decision-making process drastically, but it is important as it is seen as enabling the evolution of the treaty towards further integration.

The second shortcoming has to do with the lack of provisions that would create transparency and accountability in decision-making concerning security and defense policy. Transparency of council meetings that decide on European legislation has been increased, but these rules do not apply to security and defense. Although security and defense issues have traditionally been seen as requiring more secrecy than other issueareas, the treaty could have built in some mechanisms that would promote more open and accountable decision making. As Simon Duke notes, "little was accomplished by way of introducing greater openness and accountability into EU external relations.

24 As proposed by Mr. Wittbrodt and Mrs. Fogler, "Contribution on Enhanced Co-operation in the European Defence Policy," The European Convention, the Secretariat, CONV 846/03, Brussels, 7 July 2003. Antonio Missiroli, "European Security and Defence: The Case for Setting 'Convergence Criteria,"' European Foreign Affairs Review 4:4 (1999): 485-500.

26 Gisela Müller-Brandeck-Bocquet, "The New CFSP and ESDP Decision-Making System of the European Union," European Foreign Affairs Review 7:3 (2002): 257-82.

27 Duke, "The Convention, The Draft Constitution and External Relation," 32. 
For example, neither the European Parliament nor the European Court of Justice has any real oversight authority over ESDP.

\section{Will the New Constitutional Treaty Change Anything?}

The European Constitutional Treaty will provide the legal and institutional framework within which the EU will conduct its policies, including foreign and security policy. This essay has tried to assess the achievements of this document on the basis of clarity, democracy, and its ability to strengthen European integration. The new treaty succeeds in simplifying the treaty structure, but in the areas of foreign policy, security and defense, many articles are obscure and contradictory because they reflect political compromises on unresolved substantive issues. In particular, the treaty fails to provide a clear institutional outlook with democratic and transparent elements that would increase political accountability on the European level. While the treaty can be seen as a step forward in strengthening the role of the Union in security and defense issues, it does not offer a lasting solution for the Union to develop its security and defense dimension, as some elements of the treaty are likely to create institutional inertia or are too vague to guide policy making.

Because the treaty still awaits its ratification, in the best-case scenario it will enter into force somewhere around 2007. Many elements of the constitution in the field of security and defense, however, will be implemented already before the treaty becomes formally binding. For example, the European Armaments Agency will start its work by the end of 2004, based on decisions made by the European Council at the Brussels summits in 2003 and 2004. The solidarity clause was also adopted in the form of a political declaration after the Madrid terrorist attacks in March 2004. ${ }^{28}$ The post of the EU Foreign Minister can be created de facto by appointing a single person to the posts of Commissioner of External Relations and High Representative of the Common Foreign and Security Policy in the next commission. Structured cooperation is on the way as a commitment to form rapidly-deployable battle groups. ${ }^{29}$

Only practice will tell how the roles and the division of labor between the EU Foreign Minister, Council President, and Commission President will develop. The constitutional treaty offers few clues to resolve these tensions, but creative politicians can often make a virtue out of necessity. Indeed, the national experience suggests that security and defense policy is a notoriously difficult area to be nailed down by a constitution or any legal framework. Indeed, many of the abstract provisions simply cannot be enforced. As with the Maastricht Treaty, for example, the constitution (Art. I-39(5)) proposes that "before undertaking any action on the international scene or any commitment which could affect the Union's interests, each Member State shall consult the

28 "Declaration on Combating Terrorism," The European Council, Brussels, 25 March 2004; available at: http://ue.eu.int/ueDocs/cms_Data/docs/pressdata/en/ec/79637.pdf.

29 Gerard Quille, “'Battle Groups' to Strengthen EU Military Crisis Management?" European Security Review 22 (April 2004); available at: http://www.forum-europe.com/publication/ ESR22BattleGroup.pdf. 
others within the Council or the European Council." This did not happen before the war on Iraq in winter 2003, and it is unlikely that this provision will have any more impact, unless the governments are able to learn from their collective failures and place real priority on efforts to build common policies. 


\section{Bibliography}

Duke, Simon. "The Convention, the Draft Constitution and External Relations: Effects and Implications for the EU and its International Role." In Working Paper. Maastricht: European Institute of Public Administration, 2003.

Everts, Steven, and Daniel Keohane. "The European Convention and EU Foreign Policy: Learning from Failure." Survival 45, no. 3 (2003).

Griller, Stefan. "External Relations." In Ten Reflections on the Constitutional Treaty for Europe. Florence: The European University Institute, 2003.

Habermas, Jürgen. The Theory of Communicative Action. Boston: Beacon Press , 1986.

Hill, Christopher. "CFSP: Conventions, Constitutions and Consequentiality." International Spectator 32, no. 4 (2002): 75-8.

Jaeger, Thomas. "Enhanced Cooperation in the Treaty of Nice and Flexibility in the Common Foreign and Security Policy." European Foreign Affairs Review 7, no. 3 (2002): 297-316.

Lindley-French, Julian. "In the Shade of Locarno. Why European Defence is Failing." International Affairs 78, no. 4 (2002).

Magnette, Paul, Nicolas Jabko, Olivier Costa, and Christian Lequesne. "Conclusion: Diffuse Democracy in the European Union: The Pathologies of Delegation." Journal of European Public Policy 10, no. 5 (2003).

Mény, Yves. "De la Democratie en Europe: Old Concepts and New Challenges." Journal of Common Market Studies 4, no. 1 (2003): 1-13.

Missiroli, Antonio. "European Security and Defence: The Case for Setting "Convergence Criteria." European Foreign Affairs Review 4, no. 4 (1999).

Moravcik, Andrew. "The Myth of a European 'Leadership Crisis'." Challenge Europe 11 (2003).

Müller-Brandeck-Bocquet, Gisela. "The New CFSP and ESDP Decision-Making System of the European Union." European Foreign Affairs Review 7, no. 3 (2002): 257-82.

Scholl, Bruno. "Wie tragfähig ist die neue institutionelle Architektur der EU? Der Verfas-sungsentwurf des Konvents im Spiegel nationalstaatlicher Präferenzen." Integration 26:3 26, no. 3 (2003).

Stubb, Alexander. Negotiating Flexibility in the European Union. Basingstoke: Palgrave, 2002. 
The Solution to the 'Democratic Deficit.' A New Type of Governance for the European Union. Laurent PechJournal of European Integration 25:2 25, no. 2 (2003).

Zilmer-Johns, Lisbet. "The Convention, the IGC and the Great Powers. The ESDP and the New Security Threats." In The Politics of European Security, 55-82. Copenhagen: Danish Institute of Inter $\neg$ national Affairs, 2004. 